Vol. 1 No. 2 September 2021 e-ISSN : 2797-3344 P-ISSN : 2797-3336

\title{
PENGEMBANGAN VIDEO PEMBELAJARAN UNTUK MENINGKATKAN MOTIVASI BELAJAR SISWA SEKOLAH DASAR
}

\author{
LITA PUTRI MARLIANI \\ Universitas Islam Negeri Syarif Hidayatullah \\ e-mail: putri.marliani273@gmail.com
}

\begin{abstract}
ABSTRAK
Perkembangan teknologi saat ini memberikan pengaruh bagi dunia pendidikan, khususnya dalam media pembelajaran. Dengan adanya perkembangan teknologi, maka kita seharusnya mampu memanfaatan teknologi tersebut untuk memecahkan masalah-masalah, terutama dalam dunia pendidikan. Salah satu pemanfaatan teknologi dalam dunia pendidikan adalah menggunakan media video sebagai media pembelajaran di dalam kelas. Berdasarkan uraian tersebut, artikel ini bertujuan untuk mengkaji tentang pengembangan video pembelajaran dalam meningkatkan motivasi belajar siswa di sekolah dasar. Beberapa temuan dari kelebihan media video ini diantaranya dapat membawa dampak positif pada kegiatan belajar, salah satunya dapat meningkatkan motivasi belajar siswa sehingga pembelajaran di dalam kelas menjadi lebih menyenangkan dan membuat siswa tidak merasa bosan saat pembelajaran sedang berlangsung. Metode dalam penelitian ini menggunakan metode pendekatan kualitatif, dengan teknik analisis konten. Sumber data dalam analisis ini yakni tentang penggunaan video sebagai media pembelajaran. Dengan meningkatnya motivasi belajar, maka hasil belajar siswa pun akan meningkat. Maka, dapat disimpulkan bahwa pengembangan media video pembelajaran ini efektif digunakan dalam proses pembelajaran.
\end{abstract}

Kata Kunci: video pembelajaran, motivasi belajar, media pembelajaran.

\begin{abstract}
Current technological developments have an influence on the world of education, especially in learning media. With the development of technology, then we should be able to use the technology to solve problems, especially in the world of education. One of the uses of technology in education is to use video media as a medium of learning in the classroom. Based on this description, this article aims to examine the development of learning videos in increasing student motivation in elementary school. Some of the findings from the advantages of this video media include being able to have a positive impact on learning activities, one of which can increase student learning motivation so that learning in the classroom becomes more fun and makes students not feel bored while learning is taking place. The method in this study uses a qualitative approach, with content analysis techniques. The data source in this analysis is about the use of video as a learning medium. With increased learning motivation, student learning outcomes will also increase. So, it can be concluded that the development of this learning video media is effectively used in the learning process.
\end{abstract}

Keywords: learning videos, learning motivation, learning media.

\section{PENDAHULUAN}

Seiring dengan perkembangan zaman, teknologi informasi dan komunikasi juga semakin canggih dan sangat berkembang pesat di era saat ini. Sehingga, manusia tidak bisa menghindari dari adanya perkembangan teknologi tersebut. Pekembangan teknologi ini sangat membantu untuk mempermudah pekerjaan dan kebutuhan sehari-hari, serta menyediakan hiburan yang beragam. Dengan adanya perkembang teknologi saat ini dapat memberi pengaruh pada dunia pendidikan, khususnya dalam media pembelajaran yang digunakan dalam proses pembelajaran. Media pembelajaran adalah segala sesuatu yang dapat digunakan untuk menyalurkan pesan serta dapat memberikan rangsangan kepada siswa sehingga bisa terjadi interaksi dalam proses belajar mengajar (Ibrahim, 2005). Selain itu, media pembelajaran dapat 
diartikan sebagai alat atau sumber belajar yang digunakan untuk membantu seorang guru dalam menyampaikan pesan kepada siswa.

Salah satu media pembelajaran yang menarik bagi siswa adalah penggunaan media video/audio visual. Media audio visual adalah media yang dapat didengar dan dapat dilihat. Dengan adanya dua unsur tersebut diharapkan siswa mampu menerima, memahami, dan mengingat pesan pada proses pembelajaran. Media audio visual memiliki fungsi yaitu, dapat menarik perhatian dan memusatkan konsentrasi siswa pada materi, tujuan pembelajaran lebih cepat dicapai dengan cara memahami dan mengingat pesan pada video, serta dapat mengatasi peserta didik yang pasif dengan adanya penggunaan media yang tepat dan bervariasi. Penggunaan video pada proses pembelajaran bertujuan agar siswa lebih cepat tangkap dan memahami materi yang disampaikan. Selain itu, penyampaian materi melalui media video ini akan lebih mudah dilakukan oleh para pendidik atau guru. Pemanfaatan media video ini dapat digunakan untuk menunjang pembelajaran di kelas, terutama di sekolah dasar. Pemanfaatan media pembelajaran yang tepat dalam proses belajar mengajar di kelas dapat membawa keberhasilan bagi guru maupun siswa. Tidak hanya itu, peran guru juga sangat penting dalam proses pembelajaran, maka dari itu guru dituntut untuk bisa membuat media yang kreatif dan inovatif serta dapat memanfaatkan media pembelajaran yang tersedia di sekolah.

Penggunaan media video, motivasi belajar dan hasil belajar siswa tentunya saling berkaitan. Penggunaan video akan menimbulkan motivasi belajar siswa, motivasi belajar akan terlihat pada aktivitas siswa tersebut, dan pada akhirnya kegiatan pembelajaran akan memperoleh hasil belajar siswa yang optimal. Keberhasilan dalam proses pembelajaran dipengaruhi oleh aspek, salah satunya penggunaan strategi dalam pembelajaran di kelas. Guru dituntut untuk mempunyai strategi pembelajaran guna tercapainya tujuan belajar yang merujuk pada prestasi siswa. Selain itu, motivasi memegang peranan penting dalam proses belajar siswa. Menurut Ormrod (2009:58-59), motivasi dapat meningkatkan inisiatif dan kegigihan seseorang terhadap berbagai aktivitas. Elliott et al (2000: 332) menyatakan bahwa motivasi sebagai keadaan internal yang dapat membangkitkan semangat untuk bertindak, mendorong ke arah tertentu, dan melibatkan dalam kegiatan tertentu.

Motivasi merupakan faktor yang mendorong seseorang untuk menggerakkan segala potensi yang ada, menciptakan keinginan yang tinggi serta meningkatkan semangat sehingga tujuan yang diinginkan dapat tercapai. Motivasi sangat berperan penting dalam belajar. Dengan motivasi inilah siswa akan menjadi lebih semangat dan tekun dalam proses belajar, dan kualitas hasil belajar siswa juga kemungkinannya dapat diwujudkan.

Hal yang dapat meningkatkan motivasi belajar salah satunya adalah pengembangan video pembelajaran dalam kegiatan belajar mengajar. Hal ini sudah dijelaskan dalam penelitian yang dikembangkan oleh Syofian. Is yang berjudul "Pemanfaatan Media Video dalam Meningkatkan Motivasi Belajar Siswa Di MTsN Jambi Timur Kota Jambi" yang menyatakan bahwa pemanfaatan media video pada saat pembelajaran dapat meningkatkan Motivasi siswa kelas IX MTs N Jambi Timur Tahun Ajaran 2016/2017. Peningkatan Motivasi siswa terbukti dengan munculnya beberapa motivasi yang positif. Salah satunya siswa sangat tertarik dan berminat untuk belajar karena Media Video Pembelajaran dapat membantu para siswa dalam memahami hal-hal atau konsep yang abstrak.

Penelitian lain yang dikembangkan oleh Eko Ribawati yang berjudul "Pengaruh Penggunaan Media Video Tterhadap Motivasi dan Hasil Belajar Siswa" yang menyatakan bahwa penggunaan media video dalam pembelajaran IPS khususnya di SMP Negeri 2 Lais Musi Banyuasin sangat berpengaruh terhadap motivasi dan hasil belajar siswa. Dengan demikian penggunaan media video ini memiliki keunggulan yang dapat digunakan sebagai media dalam pembelajaran

Berdasarkan pada latar belakang di atas, maka peneliti terpacu untuk melakukan penelitan tentang pengembangan media video pembelajaran. Pengembangan media ini bertujuan untuk menghasilkan suatu produk media video pembelajaran yang valid dan efektif sebagai salah satu sumber belajar di sekolah dasar. 


\section{METODE PENELITIAN}

Metode dalam penelitian ini menggunakan metode pendekatan kualitatif dengan teknik analisis konten. Sumber data dalam analisis ini yakni tentang penggunaan video sebagai media pembelajaran. Dalam penelitian ini, memperoleh pengumpulan data yang dilakukan dengan menelusuri buku online dan artikel yang terdapat pada jurnal online. Selain itu, penelitian ini menggunakan triangulasi sumber data yang pengambilan datanya dengan cara mencari artikelartikel dari berbagai sumber. Dan terakhir, teknik analisis data dalam penelitian ini menggunakan teknik analisis mengalir Miles and Huberman.

\section{HASIL DAN PEMBAHASAN}

\section{A. Pembelajaran}

Pembelajaran merupakan proses interaksi antara peserta didik dengan pendidik, serta sumber belajar pada suatu lingkungan belajar. Menurut Hamalik proses pembelajaran adalah susunan unsur-unsur yang meliputi manusiawi, material, fasilitas, perlengkapan, dan prosedur yang saling mempengaruhi dan berkombinasi untuk mencapai tujuan pembelajaran. Proses belajar mengajar tidak terlepas dari komponen-komponen yang ada didalamnya. Masingmasing komponen saling berhubungan dan saling berpengaruh dalam setiap proses belajar mengajar yang meliputi tujuan pembelajaran, bahan pelajaran, guru/pengajar, siswa, metode, media/ alat pendidikan, situasi lingkungan belajar serta evaluasi belajar.

Dari seluruh komponen pembelajaran tersebut, artikel ini akan membahas secara rinci mengenai media pembelajaran/alat pendidikan. Media pembelajaran merupakan segala sesuatu yang dapat digunakan untuk menyampaikan pesan atau isi pelajaran, merangsang pikiran, perasaan, perhatian, dan kemampuan siswa sehingga dapat mendorong proses belajar mengajar. Dalam menggunakan media pendidikan, seorang pengajar harus memiliki pengetahuan dan pemahaman yang cukup tentang media pembelajaran/alat pendidikan agar proses pembelajaran berjalan dengan efektif.

\section{B. Media Pembelajaran \\ a. Pengertian Media Pembelajaran}

Kata media berasal dari kata latin, dalam bentuk jamak yaitu medium, yang dapat diartikan sebagai sesuatu yang terletak di tengah antara dua pihak atau suatu alat (Anitah, 2008: 1). Sedangkan menurut Smaldino et.al (2008: 7) media adalah sebuah sarana komunikasi dan sumber informasi. Dikatakan media pembelajaran, karena segala sesuatu dapat membawa pesan untuk proses pembelajaran. Media pembelajaran adalah suatu prantara yang dapat di gunakan untuk menyalurkan pesan (bahan pembelajaran) sehingga dapat merangsang perhatian, minat, pikiran, dan perasaan siswa dalam kegiatan belajar untuk mencapai tujuan pembelajaran tertentu (dalam sudatha, 2015).

\section{b. Fungsi Media Pembelajaran}

Media pembelajaran memiliki fungsi untuk memudahkan siswa dalam mempelajari materi pembelajaran, karena materi pembelajaran tidak hanya disampaikan melalui kata verbal. Riyana (2008 : 9) mengemukakan secara umum bahwa media mempunyai fungsi sebagai berikut:

1) Memperjelas pesan agar tidak terlalu verbalitas.

2) Mengendalikan keterbatasan ruang, waktu, tenaga dan daya indra.

3) Menumbuhkan semangat belajar, sehingga siswa dan sumber belajar dapat berinteraksi langsung.

4) Memungkinkan anak dapat belajar secara mandiri sesuai dengan bakat dan kemampuan visual, autitori dan kinestetiknya.

5) Memberikan rangsangan yang sama, pengalaman yang sama, dan menimbulkan persepsi yang sama. 
Vol. 1 No. 2 September 2021 e-ISSN : 2797-3344 P-ISSN : 2797-3336

\section{c. Jenis-jenis Media Pelajaran}

Media pembelajaran sangat beraneka ragam, berdasarkan klarifikasinya terdapat beberapa hal yaitu :

1. Menurut jenisnya media dibagi menjadi :
a) Media audio
b) Media visual
c) Media audio visual

2. Menurut daya liputnya, media dibagi menjadi :

a) Media memiliki daya liput yang luas dan serentak.

b) Media mempunyai daya liput yang terbatas oleh ruang dan tempat.

c) Media sebagai media pembelajaran individual seperti modul berprogram dan pembelajaran melalui komputer.

3. Menurut bahan dan pembuatannya, media dibagi kedalam :

a) Media yang sederhana.

b) Media yang kompleks.

Menurut bentuk informasi yang digunakan, media dapat dipisahkan dan diklarifikasikan dalam lima kelompok besar, yaitu media visual diam, media visual gerak, media audio, media audio visual diam, dan media audio visual gerak.

\section{d. Peran Media dalam Proses Belajar Mengajar}

1. Sebagai alat bantu mengajar

Media pembelajaran dapat memberikan pengalaman kepada peserta didik dengan pendidikan yang bermakna. Media juga dapat memberikan pengalaman yang nyata dalam proses belajar karena mengikutsertakan seluruh indra dan akal pikirannya.

Sebagaimana yang dikemukakan oleh Hamalik, beberapa faktor keuntungan atau kegunaan media, yaitu:

a. Menempatkan dasar yang nyata untuk berpikir sehingga dapat mengurangi verbalisme.

b. Dapat meningkatkan perhatian siswa.

c. Dapat menempatkan dasar yang penting untuk perkembangan belajar, sehingga membuat pelajaran lebih menetap.

d. Memberikan pengalaman yang nyata, sehingga dapat membuat siswa menjadi mandiri.

e. Menumbuhkan pikiran yang teratur dan kontinyu terutama yang terdapat dalam gambaran hidup.

f. Membantu tumbuhnya pengertian dan perkembangan kemampuan berbahasa.

g. Memberikan pengalaman yang tidak mudah diperoleh dengan cara lain serta membantu berkembangnya efesiensi yang lebih mendalam serta keragaman yang lebih banyak dalam belajar.

2. Sebagai alat komunikasi

Dengan adanya media, penyampaian pesen pendidik kepada anak didik akan lebih mudah dipahami.

3. Sebagai alat untuk menumbuhkan ciptaan baru

Agar siswa dapat terangsang untuk mengikuti pelajaran, maka guru harus menciptakan suasana belajar yang menyenangkan. Penyajian materi pelajaran tidak secara monoton, tetapi menggunakan media yang bervariasi dan sesuai, maka perhatian anak didik akan terpusat pada pelajaran yang disajikan

Dari uraian di atas, terlihat bahwa media merupakan alat bantu dalam proses pembelajaran yang diharapkan dapat membantu peserta didik untuk belajar lebih baik. Dengan demikian, suatu media bisa dikatakan baik jika media tersebut dapat membantu siswa untuk mempelajari sesuatu dengan lebih baik. 


\section{Video Pembelajaran \\ a. Pengertian Video}

Video berasal dari Istilah kata vidi atau visum yang artinya melihat atau mempunyai daya penglihatan. Video adalah gambar yang bergerak dan disertai dengan suara. Media video adalah salah satu jenis media audio visual yang dapat menggambarkan suatu objek bergerak dengan suara yang sesuai dengan isi gambar tersebut. Media video merupakan media yang memberikan informasi dalam bentuk suara dan visual. Menurut Riyana (2007 : 5), Media video adalah alat bantu yang menyajikan audio dan visual yang berisi pesanpesan pembelajaran, seperti konsep, prinsip, prosedur, dan teori guna membantu pemahaman pada materi pembelajaran. Sedangkan, menurut Arsyad (2013) Pengajaran melalui audio visual merupakan penyampaian materi yang penyerapannya melalui pandangan dan pendengaran serta tidak seluruhnya tergantung kepada pemahaman kata atau simbol-simbol yang serupa.

Media pembelajaran berfungsi sebagai alat bantu dalam proses belajar dan pembelajaran. Guru memiliki kesadaran bahwa tanpa adanya bantuan media, maka materi pembelajaran akan sulit untuk dimengerti dan dipahami oleh siswa, terutama pada pembelajaran yang rumit dan kompleks. Setiap materi pembelajaran memiliki tingkat kesulitan yang bermacam-macam. Ada pembelajaran yang membutuhkan media dan ada juga pembelajaran yang tidak membutuhkan media pembelajaran.

Dengan berkembangnya teknologi, maka munculah berbagai macam bahan ajar baru yang semakin canggih, mulai dari bahan ajar cetak, bahan ajar audio, hingga bahan ajar audio visual atau video. Dalam perkembangan tersebut dapat dilihat bahwa bahan ajar selalu mengikuti perkembangan teknologi dan ilmu pengetahuan. Pembelajaran menggunakan video dapat dicirikan dengan adanya pemakaian perangkat keras selama proses belajar, seperti proyektor film, tape recorder, dan proyektor visual lebar. Jadi pembelajaran melalui video merupakan penyampaian materi yang dapat diserap melalui penglihatan dan pendengaran.

Media video adalah salah satu media yang dapat digunakan dalam proses pembelajaran menyimak. Media video ini bisa menambah minat siswa dalam kegiatan belajar karena dapat menyimak sekaligus melihat gambar. Media video mempunyai kemampuan untuk menyajikan informasi, menjelaskan konsep-konsep yang rumit, memaparkan proses, mengajarkan keterampilan, menyingkat atau memperpanjang waktu, serta dapat mempengaruhi sikap.

\section{b. Tujuan Penggunaan Media Video}

Menurut Anderson (1987) tujuan pembelajaran dengan menggunakan media video mencakup tujuan kognitif, afektif dan psikomotor.

1. Tujuan Kognitif

a. Dapat mengembangkan kemampuan kognitif yang menyangkut dalam mengenal kembali dan mampu memberikan rangsangan berupa gerak dan sensasi.

b. Dapat menampilkan serangkaian gambar diam tanpa suara sebagaimana media foto dan film pada bingkai.

c. Dapat digunakan untuk menunjukkan contoh cara berbuat atau bersikap dalam suatu penampilan, khususnya menyangkut interaksi manusiawi.

\section{Tujuan Afektif}

Dengan adanya efek dan teknik, video dapat menjadi media yang sangat baik dalam mempengaruhi sikap dan emosi.

3. Tujuan Psikomotor

a. Video adalah media yang tepat untuk memperlihatkan contoh keterampilan yang menyangkut gerak. Gerakan tersebut bisa diperlambat maupun dipercepat

b. Melaui media video siswa bisa langsung mendapat umpan balik secara visual terhadap kemampuan mereka sehingga mereka mencoba keterampilan yang menyangkut gerakan tadi. 


\section{c. Manfaat Video}

Menurut Andi Prastowo (2012 : 302) manfaat media video, antara lain :

a. Dapat memberikan pengalaman kepada perserta didik yang tidak terduga,

b. Dapat memperlihatkan secara nyata sesuatu yang awalnya tidak mungkin bisa dilihat,

c. Dapat menganalisis perubahan dalam periode waktu tertentu,

d. Dapat memberikan pengalaman kepada peserta didik untuk merasakan suatu keadaan tertentu, dan

e. Dapat menampilkan presentasi studi kasus tentang kehidupan sebenarnya yang memicu diskusi peserta didik.

Berdasarkan penguraian di atas, dengan media video peserta didik dapat menyaksikan suatu peristiwa yang tidak bisa dilihatnya secara langsung, berbahaya, maupun peristiwa pada masa lampau. Peserta didik juga dapat memutar kembali video tersebut sesuai kebutuhan dan keperluan mereka. Pembelajaran dengan menggunakan media video dapat menumbuhkan minat serta memotivasi siswa untuk selalu memperhatikan pelajaran.

\section{d. Peran Video dalam Pembelajaran}

Penggunaan video sebagai bahan bantu dalam mengajar dapat memberikan pengalaman baru kepada peserta didik. Pengaruh media video ini akan lebih cepat masuk ke dalam diri manusia daripada media yang lainnya, karena penayangannya berupa cahaya pada titik fokus, sehingga dapat mempengaruhi fikiran dan emosi manusia. Dalam kegiatan belajar mengajar, peserta didik harus memiliki titik fokus dan penngaruh emosi dan psikologi juga sangat diperlukan. Karena dengan hal tersebut peserta didik akan lebih mudah memahami materinya dan tentunya media video yang disampaikan kepada peserta didik harus bersangkutan dengan tujuan pemebelajaran.

Menurut Hamalik, 1986: 43 (dalam Azhar, 2003: 15-16) Penggunaan media pembelajaran dalam proses belajar mengajar dapat membangkitkan keinginan dan minat yang baru, membangkitkan motivasi dan perangsang dalam kegiatan belajar, serta dapat membawa pengaruh psikologis terhadap peserta didik. Penggunaan media pengajaran pada tahap orientasi pengajaran akan sangat membantu keefektifan proses pembelajaran dan penyampaian pesan dan isi pelajaran pada proses belajar mengajar.

\section{e. Kelebihan dan Kekurangan Media Video}

Beberapa kelebihan dan kekurangan dalam penggunaan media video menurut Daryanto (2011), antara lain :

1. Kelebihan
a. Video dapat menambah dimensi baru di dalam proses pembelajaran.
b. Video dapat menampilkan gambar yang bergerak kepada peserta didik serta terdapat suara yang menyertainya.
c. Video dapat menampilkan suatu fenomena yang sulit untuk dilihat secara nyata.

2. Kekurangan
a. Opposition, pengambilan video yang kurang tepat dapat menyebabkan timbulnya keraguan bagi penonton dalam menafsirkan gambar yang dilihatnya.
b. Material pendukung, video membutuhkan alat proyeksi untuk dapat menampilkan gambar yang akan ditampilkan.
c. Budget, untuk membuat sebuah video memerlukan biaya yang tidak sedikit.

\section{Motivasi Belajar \\ a. Pengertian Motivasi}

Blok dkk. (2013) menyebutkan bahwa motivasi terbagi menjadi dua, yaitu motivasi intrinsik (dari dalam diri seseorang) dan motivasi ekstrinsik (dari luar diri seseorang). Keduanya akan saling melengkapi. Motivasi belajar merupakan mediator antara rangsangan dan reaksi. Menurut Alisuf Sabri, Motivasi adalah segala sesuatu yang menjadi pendorong tingkah laku yang menuntut seseorang untuk memenuhi kebutuhan, kemudian 
sesuatu yang dijadikan motivasi itu adalah keputusan yang telah ditetapkan individu itu sendiri sebagai suatu tujuan nyata yang ingin dicapainya.

Motivasi dipandang sebagai dorongan mental yang dapat menggerakkan dan mengarahkan perilaku manusia termasuk perilaku dalam belajar. Dalam motivasi terdapat adanya keinginan, harapan, tujuan, sasaran, dan insentif. Keadaan inilah yang dapat menggerakkan, mengaktifkan, menyalurkan, dan mengarahkan sikap dan perilaku terhadap individu (dimyati dan Mudjono, 1994).

Menurut E. Kusmana Fachrudin (2000:44) motivasi dapat dibedakan menjadi dua golongan yaitu :

1. Motivasi Asli adalah motivasi yang muncul secara kodrati sebagai dorongan pada diri manusia untuk melakukan sesuatu.

2. Motivasi Buatan merupakan motivasi yang masuk pada diri seseorang baik usaha yang disengaja maupun secara kebetulan.

Sedangkan belajar adalah perubahan tingkah laku yang terjadi pada setiap siswa sebagai hasil pengalamannya akibat adanya interaksi dengan lingkungannya. Motivasi belajar siswa meliputi dimensi:

a. Memiliki ketekunan dalam belajar

b. Gigih dalam menghadapi kesulitan

c. Memiliki ketajaman dalam perhatian belajar

d. Berprestasi dalam belajar

e. Mandiri dalam belajar

Motivasi dan belajar adalah dua hal yang saling mempengaruhi. Belajar merupakan perubahan tingkah laku secara relatif permanen dan secara potensial terjadi sebagai hasil dari penguatan yang dilandasi dengan tujuan untuk mencapai tujuan tertentu. Motivasi belajar dapat timbul karena faktor intrinsik, yang bisa berupa hasrat keinginan untuk berhasil, dorongan kebutuhan belajar, serta harapan akan cita-cita. Sedangkan faktor ekstrinsiknya bisa berupa penghargaan, lingkungan belajar yang kondusif, dan kegiatan belajar yang menarik. Tetapi perlu diingat, bahwa kedua faktor tersebut disebabkan oleh rangsangan tertentu, sehingga seseorang berkeinginan untuk melakukan aktivitas belajar yang lebih giat dan semangat.

Hakikat motivasi belajar adalah dorongan intermal dan ekstermal pada siswa-siswa yang sedang belajar untuk mengadakan perubahan tingkah laku, pada umumnya dengan beberapa indikator atau unsur yang mendukung. Indikator motivasi belajar menurut Uno (2014) dapat diklasifikasikan menjadi :

a) Adanya keinginan untuk berhasil.

b) Adanya dorongan dan kebutuhan untuk belajar.

c) Adanya harapan dan cita-cita untuk masa depan.

d) Adanya apresiasi dalam pembelajaran.

e) Adanya kegiatan yang menarik dalam pembelajaran.

f) Adanya lingkungan belajar yang kondusif, sehingga siswa bisa untuk belajar dengan baik.

\section{b. Faktor yang Mempengaruhi Motivasi Belajar}

1. Faktor dari dalam yaitu faktor dari dalam diri siswa yang bisa mempengaruhi proses dan hasil belajar. Faktor ini meliputi cita-cita siswa, kemampuan belajar siswa, kondisi siswa, kondisi lingkungan, unsur-unsur dinamis dalam belajar, dan upaya guru mengajarkan siswa.

2. Faktor dari luar yaitu faktor yang berasal dari luar siswa yang bisa mempengaruhi proses dan hasil belajar. Faktor ini meliputi lingkungan sosial. Yang dimaksud dengan lingkungan sosial di sini yaitu sesama manusia. Lingkungan sosial tersebut yaitu lingkungan siswa di sekolah yang terdiri dari teman sebaya, teman kelas lain, guru, kepala sekolah serta karyawan lainnya yang bisa mempengaruhi proses dan hasil belajar individu. 
3. Faktor instrumen yaitu faktor yang berhubungan dengan perangkat pembelajaran seperti kurikulum, struktur program, sarana dan prasarana pembelajaran (media pembelajaran), serta guru sebagai perancang pembelajaran.

\section{c. Peran dan Fungsi Motivasi dalam Belajar}

Dengan motivasi siswa akan bersungguh-sungguh dalam proses belajar, dan dengan motivasi inilah kualitas hasil belajar siswa dapat diwujudkan. Dalam proses pembelajaran siswa akan mempunyai motivasi yang kuat dan jelas untuk memperoleh hasil yang diharapkan. Motivasi memiliki fungsi, sebagai berikut:

1) Pendorong seseorang dalam berbuat sesuatu untuk mencapai tujuannya.

2) Penentu arah perbuatan yang hendak dicapai.

3) Menyeleksi perbuatan, sehingga perbuatan seseorang yang memiliki motivasi senantiasa selektif dan tetap terarah kepada tujuan yang ingin dicapai.

Berdasarkan arti dan fungsi motivasi dapat disimpulkan bahwa motivasi tidak hanya berfungsi sebagai penentu terjadinya suatu perbuatan tetapi penentu dari hasil perbuatan juga. Motivasi akan mendorong seseorang untuk bekerja atau melakukan suatu perbuatan dengan bersungguh-sungguh dan akhirnya akan menentukan pula hasil dari pekerjaannya.

\section{KESIMPULAN}

Video adalah gambar yang bergerak dan disertai dengan suara. Media video adalah salah satu jenis media audio visual yang dapat menggambarkan suatu objek bergerak dengan suara yang sesuai dengan isi gambar tersebut. Motivasi dipandang sebagai dorongan mental yang dapat menggerakkan dan mengarahkan perilaku manusia termasuk perilaku dalam belajar. Dalam motivasi terdapat adanya keinginan, harapan, tujuan, sasaran, dan insentif.

Media video ini bisa menambah minat serta motivasi siswa dalam kegiatan belajar karena dapat menyimak sekaligus melihat gambar. Media video mempunyai kemampuan untuk menyajikan informasi, menjelaskan konsep-konsep yang rumit, memaparkan proses, mengajarkan keterampilan, menyingkat atau memperpanjang waktu, serta dapat mempengaruhi sikap.

Dengan pengembangan media video dalam kegiatan pembelajaran ini dapat meningkatkan motivasi belajar siswa, khususnya motivasi siswa dalam mengikuti kegiatan pembelajaran di kelas. Dan dengan meningkatnya keterlibatan siswa dalam kegiatan pembelajaran pada akhirnya dapat menunjang peningkatan pencapaian hasil belajar. Dengan meningkatnya motivasi belajar, maka hasil belajar siswa pun akan meningkat. Maka, dapat disimpulkan bahwa pengembangan media video pembelajaran ini efektif digunakan dalam proses pembelajaran.

\section{DAFTAR PUSTAKA}

Agustini, K., \& Ngarti, J. G. (2020). Pengembangan Video Pembelajaran Untuk Meningkatkan Motivasi Belajar Siswa Menggunakan Model R \& D. Jurnal Ilmiah Pendidikan Dan Pembelajaran, 4(April 2020), 62-78.

Arianti, A. (2019). Peranan Guru Dalam Meningkatkan Motivasi Belajar Siswa. DIDAKTIKA : Jurnal Kependidikan, 12(2), 117-134.

Aritonang, K. T. (2008). Minat dan motivasi dalam meningkatkan hasil belajar siswa. Jurnal pendidikan penabur, 7(10), 11-21.

Fadhli, M. (2015). Pengembangan Media Pembelajaran Berbasis Video Kelas Iv Sekolah Dasar. Jurnal Dimensi Pendidikan Dan Pembelajaran, 3(1), 24-29.

Farista, R., \& M, I. A. (2018). Pengembangan Video Pembelajaran. Universitas Muhammadiyah Sidoarjo, 53(9), 1689-1699.

Hadi, S. (2017). Efektivitas Penggunaan Video Sebagai Media Pembelajaran untuk Siswa Sekolah Dasar. Prosiding TEP \& PDs, 1(15), 96-102. 
Huda, I. A. (2020). Perkembangan Teknologi Informasi Dan Komunikasi (Tik) Terhadap Kualitas Pembelajaran Di Sekolah Dasar. Jurnal Pendidikan Dan Konseling (JPDK), 2(1), 121-125.

Is, S. I. (2020). Pemanfaatan Media Video Dalam Meningkatkan Motivasi Belajar Siswa Di MTsN Jambi Timur Kota Jambi. Jurnal Literasiologi, 3(1), 1-14.

Lin, M. H., Chen, H. C., \& Liu, K. S. (2017). A study of the effects of digital learning on learning motivation and learning outcome. Eurasia Journal of Mathematics, Science and Technology Education, 13(7), 3553-3564.

Manzilatusifa, U. (2017). Pemberian Motivasi Guru Dalam Pembelajaran. Educare, 5(1), 6773.

Novita, L., Sukmanasa, E., \& Pratama, M. Y. (2019). Penggunaan Media Pembelajaran Video terhadap Hasil Belajar Siswa SD. Indonesian Journal of Primary Education Penggunaan, 3(2), 64-72.

Pakpahan, Andrew F, dkk. (2020). Pengembangan Media Pembelajaran (A. \& S. P. Karim (ed.); ke1). Yayasan Kita Menulis, Sumatera Utara.

Puspitarini, Y. D., \& Hanif, M. (2019). Using Learning Media to Increase Learning Motivation in Elementary School. Anatolian Journal of Education, 4(2), 53-60.

Ribawati, E. (2015). Pengaruh Penggunaan Media Video Terhadap Motivasi Dan Hasil Belajar Siswa. Candrasangkala : Jurnal Pendidikan Dan Sejarah, 1(1), 134-145.

Suardi, M. (2018). Belajar dan Pembelajaran (H. \& R. S. Rahmadhani (ed.); ke 1). DEEPUBLISH, Yogyakarta.

Syaparuddin, S., \& Elihami, E. (2020). Peningkatan Motivasi Belajar Siswa Melalui Video Pada Pembelajara PKn Di Sekolah Paket C . Jurnal Edukasi Nonformal, 1(1), 187200.

Uno, B. H. (2016). TEORI MOTIVASI \& PENGUKURANNYA : Analisi Di Bidang Pendidikan (Junwinanto (ed.); ke14). Bumi Aksara, Jakarta.

Wisada, P. D., Sudarma, I. K., \& Yuda S, A. I. W. I. (2019). Pengembangan Media Video Pembelajaran Berorientasi Pendidikan Karakter. Journal of Education Technology, 3(3), 140.

Wuryanti, U., \& Kartowagiran, B. (2016). Pengembangan Media Video Animasi Untuk Meningkatkan Motivasi Belajar Dan Karakter Kerja Keras Siswa Sekolah Dasar. Jurnal Pendidikan Karakter, 6(2), 232-245.

Yuanta, F. (2020). Pengembangan Media Video Pembelajaran Ilmu Pengetahuan Sosial pada Siswa Sekolah Dasar. Trapsila: Jurnal Pendidikan Dasar, 1(02), 91.

Yudianto, A. (2017). Peran Video Sebagai Media Pembelajaran. Seminar Nasional Pendidikan. 